\title{
Antinociceptive activity of Hypericum caprifoliatum and Hypericum polyanthemum (Guttiferae)
}

A.F. Viana ${ }^{1,2}$, A.P. Heckler ${ }^{1}$, R. Fenner ${ }^{1}$ and S.M.K. Rates ${ }^{1,2}$

\author{
'Laboratório de Psicofarmacologia, Departamento de Produção de Matéria Prima, \\ Faculdade de Farmácia, Universidade Federal do Rio Grande do Sul, Porto Alegre, \\ RS, Brasil \\ 2Programa de Pós-Graduação em Ciências Farmacêuticas, \\ Universidade Federal do Rio Grande do Sul, Porto Alegre, RS, Brasil
}

\footnotetext{
Correspondence

S.M.K. Rates

Faculdade de Farmácia, UFRGS

Av. Ipiranga, 2752

90610-000 Porto Alegre, RS

Brasil

Fax: +55-51-3316-5437

E-mail: ratessmk@farmacia.ufrgs.br

Presented at the XVII Annual Meeting of the Federação de Sociedades de Biologia Experimental, Salvador, BA, Brazil, August 28-31, 2002.

R. Fenner, A.P. Heckler,

S.M.K. Rates and A.F. Viana were the recipients of fellowships from PROPESQ-UFRGS, CNPq and CAPES, respectively.
}

Received April 18, 2002 Accepted February 17, 2003

\begin{abstract}
The aim of the present study was to assess the analgesic activity of the aerial parts of two Hypericum species native to Southern Brazil, $H$. caprifoliatum and $H$. polyanthemum. The antinociceptive effect of the H. polyanthemum cyclohexane extract (POL; $180 \mathrm{mg} / \mathrm{kg}$ ) and of the $H$. caprifoliatum methanol (MET) and cyclohexane $(\mathrm{CH})$ extracts $(90$ $\mathrm{mg} / \mathrm{kg}$ ) was evaluated in the hot-plate (ip and $p o$ ) and writhing ( $p o$ ) tests using male Swiss CF1 mice weighing $22-27 \mathrm{~g}(\mathrm{~N}=10$ per group). All extracts displayed antinociceptive effects in the hot-plate test $(\mathrm{MET} i p=48 \%$, MET $p o=39 \%, \mathrm{CH} i p=27 \%, \mathrm{CH} p o=50 \%$, POL ip $=74 \%$, and POL $p o=49 \%$ compared to control). Pretreatment with naloxone $(2.5 \mathrm{mg} / \mathrm{kg}, s c)$ abolished the effects of $\mathrm{CH}$ and POL, and partially prevented the analgesia induced by MET administered by the ip (but not by the $p o$ ) route. POL and $\mathrm{CH}(p o$ ) significantly reduced the number of writhes induced by acetic acid, while MET was ineffective in this regard. We conclude that the antinociceptive effects of the $H$. caprifoliatum $(\mathrm{CH})$ and $H$. polyanthemum $(\mathrm{POL})$ hexane extracts seem to be mediated by the opioid system. Moreover, the antinociceptive activity of the $H$. caprifoliatum MET extract seems to depend on at least two chemical substances (or groups of substances) with distinct pharmacokinetic profiles and mechanisms of action. Only the naloxone-insensitive component of MET activity showed good bioavailability following oral administration.
\end{abstract}

Key words

- Hypericum caprifoliatum

- Hypericum polyanthemum

- Analgesia

- Antinociception

- Hot-plate test

- Writhing test
The chemical investigation of the genus Hypericum (Guttiferae), which comprises approximately 400 species (1), has led to the isolation of more than 100 compounds from about 20 species with various different biological activities, especially antiviral, antimicrobial and antidepressant properties. $H$. perforatum extracts are widely used in Europe, in the United States, and also in Brazil, for the treatment of mild to moderate depression (2).

The Southern Brazilian Hypericum species $H$. brasiliensis and $H$. connatum are popularly used for relief of disorders such as angina, cramps and oral and pharyngeal inflammations, which suggests an analgesic property for this genus (3).

Previous reports published by our group 
have shown interesting biological activities for the Hypericum species native to the State of Rio Grande do Sul, Brazil. A crude lipophilic extract of $H$. caprifoliatum induces an anti-immobility effect in the forced swimming test (4), which is considered to indicate an antidepressant action (5), as well as an antinociceptive effect in the hot-plate test (6). H. caprifoliatum, H. piriai and H. polyanthemum showed in vitro monoamine oxidase A-inhibitory activity (7). The aim of the present study was to investigate further the antinociceptive effects of $H$. caprifoliatum and to start the characterization of the antinociceptive properties of $H$. polyanthemum.

Air-dried and powdered aerial parts of $H$. caprifoliatum and $H$. polyanthemum were extracted with cyclohexane using an ultraturrax apparatus $(3 \times 5 \mathrm{~min}$; plant/solvent ratio 1:10, w/v), yielding extracts termed $\mathrm{CH}$ and POL, respectively. In order to obtain an extract rich in polar substances, $H$. caprifoliatum was also extracted consecutively in a Soxhlet apparatus with petroleum ether, chloroform and methanol (MET) and only the MET extract was used. All solvents were evaporated to dryness under reduced pressure. The extract was dissolved in saline solution containing $2.5 \%(\mathrm{w} / \mathrm{v})$ polysorbate 80. The $\mathrm{pH}$ of the final solutions was 6.5 to 7.0. The volume administered was $1 \mathrm{ml} / 100$ g body weight for the analgesic tests.

Male Swiss CF1 mice (22-27 g) from the breeding colony of Fundação Estadual de Pesquisa e Ensino em Saúde (FEPPS, RS, Brazil) were used. The animals were housed in plastic cages, 5 to a cage, under a 12-h light/dark cycle (lights on at 7:00 h) at constant temperature $\left(23 \pm 1^{\circ} \mathrm{C}\right)$, with free access to standard certified rodent diet and tap water. The experiments were performed according to the guidelines of the National Ethics Committee on Research, Brazilian National Health Council. Ten mice per group were used for all experiments.

Before actual testing on the hot plate, the mice were habituated to the nonfunctioning apparatus for $1 \mathrm{~min}$. Thirty minutes later, the animals were placed on the functioning hot plate (Ugo Basile, Comerino, Italy) to determine baseline responsiveness $10 \mathrm{~min}$ before treatment with $90 \mathrm{mg} / \mathrm{kg} \mathrm{CH}$ or MET or 180

\begin{tabular}{|c|c|c|c|}
\hline \multirow[t]{2}{*}{ Treatment (administration) } & \multicolumn{2}{|c|}{ Latency (s) } & \multirow[t]{2}{*}{$\%$ Analgesia } \\
\hline & Before treatment & After treatment & \\
\hline Control (saline $+2.5 \%$ polysorbate 80 ) & $12.1 \pm 0.8$ & $12.0 \pm 1.4$ & 0 \\
\hline MOR $(6 \mathrm{mg} / \mathrm{kg}, \mathrm{sc})$ & $10.2 \pm 1.2$ & $27.9 \pm 1.9^{*}$ & 100 \\
\hline MET (90 mg/kg, ip) & $12.0 \pm 1.8$ & $20.5 \pm 3.7^{*}$ & 48.4 \\
\hline $\mathrm{CH}(90 \mathrm{mg} / \mathrm{kg}, \mathrm{ip})$ & $9.4 \pm 1.5$ & $14.2 \pm 1.8^{*}$ & 27.3 \\
\hline POL (180 mg/kg, ip) & $10.2 \pm 1.8$ & $23.1 \pm 3.9^{*}$ & 73.8 \\
\hline $\mathrm{NAL}(2.5 \mathrm{mg} / \mathrm{kg}, \mathrm{sc})+\mathrm{MOR}(6 \mathrm{mg} / \mathrm{kg}, \mathrm{sc})$ & $10.3 \pm 1.3$ & $10.8 \pm 1.5$ & 3.1 \\
\hline $\mathrm{NAL}(2.5 \mathrm{mg} / \mathrm{kg}, \mathrm{sc})+\mathrm{CH}(90 \mathrm{mg} / \mathrm{kg}, i p)$ & $11.4 \pm 1.3$ & $11.2 \pm 2.0$ & 0 \\
\hline NAL $(2.5 \mathrm{mg} / \mathrm{kg}, \mathrm{sc})+\mathrm{MET}(90 \mathrm{mg} / \mathrm{kg}, i p)$ & $9.7 \pm 1.4$ & $15.6 \pm 2.4^{*}$ & 30.8 \\
\hline $\mathrm{NAL}(2.5 \mathrm{mg} / \mathrm{kg}, \mathrm{sc})+\mathrm{POL}(180 \mathrm{mg} / \mathrm{kg}, i p)$ & $12.37 \pm 1.3$ & $12.6 \pm 3.1$ & 1.5 \\
\hline $\mathrm{CH}(90 \mathrm{mg} / \mathrm{kg}, \mathrm{po})$ & $9.2 \pm 0.9$ & $17.8 \pm 1.7^{*}$ & 50 \\
\hline MET (90 mg/kg, po) & $10.5 \pm 0.8$ & $17.4 \pm 2.1^{*}$ & 39.2 \\
\hline $\mathrm{POL}(180 \mathrm{mg} / \mathrm{kg}, \mathrm{po})$ & $12.26 \pm 1.8$ & $20.7 \pm 2.5^{*}$ & 48.6 \\
\hline $\mathrm{NAL}(2.5 \mathrm{mg} / \mathrm{kg}, \mathrm{sc})+\mathrm{CH}(90 \mathrm{mg} / \mathrm{kg}, \mathrm{po})$ & $12.8 \pm 1.5$ & $11.1 \pm 0.6$ & 0 \\
\hline NAL $(2.5 \mathrm{mg} / \mathrm{kg}, \mathrm{sc})+\mathrm{MET}(90 \mathrm{mg} / \mathrm{kg}, \mathrm{po})$ & $10.2 \pm 1.0$ & $16.6 \pm 2.7^{*}$ & 36.5 \\
\hline
\end{tabular}


$\mathrm{mg} / \mathrm{kg}$ POL (ip and $p o$ ). Treatment-induced changes in responsiveness to the hot plate were determined 30 and 45 min after ip and po administration, respectively. The negative control group received an equal volume of vehicle (saline $+2.5 \%(\mathrm{w} / \mathrm{v})$ polysorbate $80)$. Morphine $(6 \mathrm{mg} / \mathrm{kg}, s c)$ was administered to the positive control group. To determine the possible involvement of opioidmediated mechanisms, some groups of animals were pretreated with naloxone $(2.5 \mathrm{mg} /$ $\mathrm{kg}, s c$ ), a nonspecific opioid receptor antagonist, immediately after evaluating baseline responsiveness, $10 \mathrm{~min}$ before extract administration.

For the hot-plate test, mice were placed on a metal surface kept at $53 \pm 1{ }^{\circ} \mathrm{C}$. The time elapsed until the animal licked one of its hind paws or jumped was recorded (latency time, in s) and considered to be the reaction time in both exposures. Mice that presented baseline reaction times of more than $15 \mathrm{~s}$ in the first session were not used. In the second session, a maximum latency time of $30 \mathrm{~s}$ was imposed in order to avoid tissue damage.

The data were analyzed by the paired Student $t$-test, considering the animal as its own control (second measure $v s$ first measure). The results obtained in the hot-plate test are reported as the mean $\pm \mathrm{SEM}$ absolute latency time or as the percent of antinociceptive effect relative to morphine $(6 \mathrm{mg} / \mathrm{kg}, s c)$ according to the following formula: $\%$ analgesia $=\left(\right.$ test $_{\text {after }}-$ test $\left._{\text {before }}\right) /\left(\right.$ morphine $_{\text {after }}-$ morphine $\left._{\text {before }}\right) \times 100$.

The animals were treated with $\mathrm{CH}, \mathrm{MET}$ (90 mg/kg, po) or POL (180 mg/kg, po) for the writhing test $45 \mathrm{~min}$ before receiving an ip injection of $0.8 \%$ acetic acid. Mice were then placed individually in glass observation chambers and the number of abdominal writhes was counted over a period of $15 \mathrm{~min}$. The control group received an equal volume of vehicle (saline $+2.5 \%(\mathrm{w} / \mathrm{v})$ polysorbate $80, p o)$. Dipyrone $(150 \mathrm{mg} / \mathrm{kg}, p o)$ was the positive control treatment. Previous experiments carried out in our laboratory have revealed that none of the extracts caused any signs of pain or writhes per se, in mice, when injected ip (8). The results obtained in the writhing test are reported as median values and their respective interquartile intervals, and were analyzed by the Kruskal-Wallis test.

All extracts displayed antinociceptive effects in the hot-plate test (Table 1). Pretreatment with naloxone abolished the effects of $\mathrm{CH}$ and $\mathrm{POL}$, indicating that these effects are produced by opioid-mediated mechanisms. Conversely, antinociception produced by MET administered $i p$ was only partially prevented by naloxone, whereas the po antinociceptive activity was not modified, indicating that opioid-like substances present in this extract were not absorbed by the gastrointestinal tract or suffered singlepass inactivation by the liver. In addition, the percent of analgesia was higher when MET was administered by the ip route compared to the po route.

Administration of $\mathrm{CH}$ and $\mathrm{POL}$ significantly reduced the number of abdominal writhes induced by acetic acid, whereas MET did not have a significant effect (Table 2). Interestingly, the magnitude of the antinociceptive effect of $\mathrm{CH}$ in the writhing test (oral route) was similar to that observed in the

Table 2. Analgesic effects of methanol (MET) and cyclohexane $(\mathrm{CH})$ extracts of aerial parts of Hypericum caprifoliatum $(90 \mathrm{mg} / \mathrm{kg}, \mathrm{po})$ and of the cyclohexane extract of aerial parts of $\mathrm{H}$. polyanthemum (POL, $180 \mathrm{mg} / \mathrm{kg}, \mathrm{po}$ ) on writhing induced by $0.8 \%$ acetic acid (ip) in mice.

\begin{tabular}{lcc}
\hline Treatment & Number of writhes & $\begin{array}{c}\text { \% Reduction of abdominal writhing } \\
\text { compared to control }\end{array}$ \\
\hline Control & $58(55-65)$ & - \\
DIP & $0(2-16)^{*}$ & 100 \\
MOR & $0(0-3)^{*}$ & 100 \\
CH & $24(0-34.5)^{*}$ & 58.6 \\
MET & $40.5(16-59)$ & 30.2 \\
POL & $0(0-10)^{*}$ & 100
\end{tabular}

Control (saline + 2.5\% polysorbate 80); DIP (dipyrone, $150 \mathrm{mg} / \mathrm{kg}, \mathrm{po}$ ); MOR (morphine, $10 \mathrm{mg} / \mathrm{kg}$, po).

\#Values are reported as medians (interquartile intervals).

${ }^{*} \mathrm{P}<0.001$ compared to control (Kruskal-Wallis, $\mathrm{H}=30.235$ ) 
hot-plate test, while the effect of POL was more pronounced in the writhing test. Thus, the antinociceptive properties of POL might be due to actions on both central and peripheral pain systems. Apparently, the antinociceptive activity is not correlated with the antidepressant activity previously reported. Although lipophilic extracts of $H$. caprifoliatum were active in the Porsolt test $(1,6)$, the same was not true for MET or POL $(4,7)$.

The $\mathrm{CH}$ extract is rich in phloroglucinol (7) and the POL extract contains benzopyrans as its main constituent (9). Phloroglucinol derivatives may be responsible for the opioidlike effect since Simmen et al. (10) have reported that hyperforin - a phloroglucinol isolated from H. perforatum - inhibited binding to opioid receptors. With respect to the benzopyrans as well as the flavonoid derivatives, which are present in MET (Dall'Agnol R, Ferraz A, Schapoval ES and von Poser G, unpublished data), we are unaware of any previous reports on their influence/action on opioid systems. None of the extracts $(\mathrm{CH}$, POL or MET) contains hypericin (11).

In conclusion, extracts obtained from both species, $H$. caprifoliatum and $H$. polyanthemum, contain compounds with substantial antinociceptive properties related, at least in part, to activation of opioid-mediated mechanisms. Further studies are in progress in order to elucidate the mechanisms underlying the antinociceptive effects of these species.

\section{Acknowledgments}

The authors are indebted to Dr. Sérgio Bordignon, Curso de Ciências Biológicas, Centro Universitário La Salle, for collecting and identifying the plant material, and to Dr. Gilsane Lino von Poser's group, Programa de Pós-Graduação em Ciências Farmacêuticas, Universidade Federal do Rio Grande do Sul, for helping with the extract preparation.

\section{References}

1. Robson NKB (1990). Studies in the genus Hypericum L. (Guttiferae) 8. Section 29. Brathys (Part 2) and 30. Trigynobrathys. Bulletin of the British Museum (Botany), 20: 1-151.

2. Barnes J, Anderson LA \& Phillipson D (2001). St John's wort (Hypericum perforatum L.): a review of its chemistry, pharmacology and clinical properties. Journal of Pharmacy and Pharmacology, 53: 583600.

3. Mentz LA, Lutzemberger LC \& Schenkel EP (1997). Da flora medicinal do Rio Grande do Sul: notas sobre a obra de D'Avila (1910). Cadernos de Farmácia, 15: 25-47.

4. Daudt R, Von Poser GL, Neves G \& Rates SMK (2000). Screening for the antidepressant activity of some species of Hypericum from South Brazil. Phytotherapy Research, 14: 344-346.

5. Porsolt RD, Anton G \& Blavet N (1978). Behavioral despair in rats: a new model sensitive to antidepressant treatments. European Journal of Pharmacology, 47: 379-381.

6. Viana AF, Sória A, Ferraz A, Daudt R, Bordignon S, Von Poser GL \& Rates SMK (1999). Atividade antidepressiva e analgésica de Hypericum caprifoliatum Cham. \& Schledt (Guttiferae). In: Henriques AT (Editor), IX Simpósio Latino-Americano de Farmacobotânica e III
Reunião Latino-Americana de Fitoquímica, Gramado, RS, Brazil, September 1999, 175.

7. Gnerre C, Von Poser GL, Ferraz A, Viana AF, Testa B \& Rates SMK (2001). Monoamine oxidase inhibitory activity of some Hypericum species native to South Brazil. Journal of Pharmacy and Pharmacology, 53: 1273-1279.

8. Viana AF (2002). Estudo da atividade psicofarmacológica de espécies de Hypericum nativas do Rio Grande do Sul e toxicidade aguda de Hypericum caprifoliatum Cham. \& Schledt. Master's thesis, Universidade Federal do Rio Grande do Sul, Porto Alegre, RS, Brazil.

9. Ferraz ABF, Bordignon SAL, Staats C, Schripsema J \& Von Poser GL (2001). Benzopyrans from Hypericum polyanthemum. Phytochemistry, 57: 1227-1230.

10. Simmen U, Higelin J, Berger-Büter K, Schaffner W \& Lundstrom K (2001). Neurochemical studies with St. John's wort in vitro. Pharmacopsychiatry, 34 (Suppl 1): s137-s142.

11. Ferraz A, Bordignon S, Mans D, Schmitt A \& Ravazzolo AP (2002). Screening for the presence of hypericins in southern Brazilian species of Hypericum (Guttiferae). Pharmaceutical Biology, 40: 294297. 